\title{
An interesting case of acute bilateral upper motor weakness: A case report
}

\author{
İlginç bir vaka olarak bilateral üst motor zayıflık: Bir olgu sunumu
}

\section{Shamsudeen Moideen ${ }^{1}$, N.A. Uvais ${ }^{2}$}

\begin{abstract}
Malaria, the world's third-ranked infectious killer, is caused by the bite of a female anopheline mosquito which is infected a protozoan from the genus 'Plasmodium'. More than $35 \%$ of all malaria cases are caused by the falciparum malaria species. Several neurological manifestations of malaria have been reported, especially with severe falciparum infection, which in- clude altered level of consciousness, repeated seizures and coma. Here, we report a unique case of acute bilateral upper motor neuron weakness due to $\mathrm{P}$. Falciparum malaria in a previously healthy young adult, who is a migrant worker in Kerala/India.

Keywords: Upper motor neuron, Malaria, Cerebral, Non-endemic
\end{abstract}

Öz

Dünyanın üçüncü enfeksiyöz ölümcül hastalığı olan sıtma, plazmodyum türü protozoon tarafından enfekte edilmiş dişi anofel cinsi sivrisineği ısırığından kaynaklanır. Tüm sıtma vakalarının \%35'ten fazlası falciparum malaria türü kaynaklıdır. Sıtmanın bazı nörolojik semptomları, özellikle şiddetli falciparum enfeksiyonu ile beraber olduğunda; şuur değişikliği, tekrarlayan nöbetler ve koma olarak bildirilmiştir. Burada, Hindistan'ın Kerela bölgesinde göçmen işçi olarak çalışan, önceden sağlıklı genç bir erişkinde plasmodyum falciparum kaynaklı sıtmaya bağlı akut bilateral motor nöron zayıflı̆̆ı hakkında özgün bir vaka sunuyoruz.

Anahtar kelimeler: Üst motor nöron, Sitma, Beyin, Endemik olmayan

\section{Introduction}

Malaria is the world's third-ranked infectious killer disease after Human Immunodeficiency virus / Acquired Immune Deficiency Syndrome (HIV/AIDS) and tuberculosis [1]. Every year malaria causes clinical illness in over 300-500 million people globally and over 1 million people die from it every year [2].

Malaria is caused by the bite of a female anopheline mosquito which is infected a protozoan from the genus 'Plasmodium' of which there are four human species: Plasmodium vivax, Plasmodium falciparum, Plasmodium ovale and Plasmodium malaria [3]. More than 35\% of all malaria cases is caused by the falciparum malaria species [3]. Several neurological manifestations of malaria have been reported, especially with severe falciparum infection.

Cerebral malaria is characterized by dysfunction of any organ system, which includes neurological involvement leading to altered level of consciousness, repeated seizures and coma.

Malaria has been a problem in India for centuries. According to the World Malaria Report 2014, 22\% (275.5m) of India's population live in high transmission ( $>1$ case per 1000 population) areas, $67 \%(838.9 \mathrm{~m})$ live in low transmission (0-1 cases per 1000 population) areas and $11 \%(137.7 \mathrm{~m})$ live in malaria free (zero cases) areas [4]. The state of Orissa contributes about $25 \%$ of the total annual malaria cases, more than $40 \%$ of P. falciparum malaria cases and nearly $20-30 \%$ of deaths caused by malaria in India, followed by Meghalaya, Mizoram, Maharashtra, Rajasthan, Gujarat, Karnataka, Goa, southern Madhya Pradesh, Chhattisgarh, and Jharkhand [5].

Here, we report a unique case of acute bilateral upper motor neuron weakness due to P. Falciparum malaria in a previously healthy young adult, who is a migrant worker in Kerala/India. This case report highlights the uncommon presentations of falciparum malaria which clinicians should be aware of while making differential diagnosis even in non-endemic zones for malaria.

\author{
${ }^{1}$ Department of Internal Medicine, Iqraa \\ International Hospital and Research Centre, \\ Calicut, Kerala, India \\ ${ }^{2}$ Department of Neuropsychiatry, Iqraa \\ International Hospital and Research Centre, \\ Calicut, Kerala, India
}

Çıkar Çatı̧̧ması: Yazarlar çıkar çatışması bildirmemişlerdir.

Conflict of Interest: No conflict of interest was declared by the authors.

Finansal Destek: Yazarlar bu olgu için finansal destek almadıklarını beyan etmişlerdir.

Financial Disclosure: The authors declared that this case has received no financial support.

Geliş Tarihi / Received: 19.11.2017

Kabul Tarihi / Accepted: 21.12.2017

Yayın Tarihi / Published: 16.02.2018

Sorumlu yazar / Corresponding author N.A.Uvais

Adres/Address: Iqraa International Hospital and

Research Centre, Calicut, Kerala, India.

Phone: 09562685573

e-Mail: druvaisna@gmail.com

Copyright (C) ACEM 


\section{Case report}

A 25-year-old gentle man from Rajasthan (Northern India) who was working in a granite industry in Kerala (South India) presented to the hospital with complaints of fever for 5 days. The fever was sudden in onset, high grade with chills and rigor. Headache and vomiting developed the next day. He had several episodes of vomiting which was non projectile and nonbilious in nature. It was learned that he had developed sudden deterioration of his level of consciousness three days prior to admission. One day prior to the admission he developed breathing difficulty and was taken to a nearby hospital, where he was intubated. There was no history of cough, chest pain, palpitation, abdominal pain, loose stools or seizures. A detailed history was elicited which suggested no significant past illnesses or any significant illnesses in the family. He had a history of travel to a native state, Rajasthan, recently.

On clinical examination, it was seen that he was intubated and on $\mathrm{T}$ piece. He was conscious and obeyed commands. His breathing was spontaneous with a respiratory rate of $24 / \mathrm{min}$. His pulse rate was $76 / \mathrm{min}$ and blood pressure was $110 / 80 \mathrm{mmHg}$. His body temperature was $98.6^{\circ} \mathrm{F}$ and $\mathrm{SpO} 2$ was $98 \%$.

Central nervous system examination showed grade 1 power in both up- per and lower limbs, with exaggerated deep tendon reflexes, and bilateral extensor plantar response. There was no cranial nerve involvement, neck stiffness or extrapyramidal signs. Skull and spine was normal. Physical examination finding in relation with cardio vascular, gastro intestinal and respiratory systems were all normal. His laboratory results are summarized in Table 1 . Routine urinary examination was normal.

Study of cerebrospinal fluid was unremarkable. Malaria card test was positive and peripheral smear showed plasmodium falciparum. Magnetic resonance imaging (MRI) of the cervical spine done to rule out spinal pathologies was normal. MRI of the brain showed hyper-intensity over the splenium, the corona radiata and the basal ganglia, with mild diffuse brain edema (Figure 1,2). Blood cultures showed no bacterial growth.

Patient was admitted in medical intensive care unit and treated with intravenous injection Artesunate $2.4 \mathrm{mg} / \mathrm{kg}$ IV at 0 and 12 hours, along with other supportive measures including intravenous mannitol. The next day, the patient became well and his level of consciousness improved. He was extubated on the same day and shifted to the ward on day 3. Intravenous injection Artesunate $2.4 \mathrm{mg} / \mathrm{kg}$ was continued once a day for the next five days. At the time of discharge, he was fully conscious and oriented with full power in all four limbs. Written consent was taken from the patient.

Table 1: Patient's laboratory tests

\begin{tabular}{|c|c|c|}
\hline Tests & Values & Normal range \\
\hline$\overline{\text { Hemoglobin (gm\%) }}$ & 10.1 & $14-18$ \\
\hline $\begin{array}{l}\text { Total count }\left(\text { cells } / \mathrm{mm}^{3}\right) \\
\text { Differential count }(\%)\end{array}$ & 8,400 & $4,500-11,000$ \\
\hline Neutrophils & 74 & $50-70$ \\
\hline Lymphocytes & 18 & $25-50$ \\
\hline Monocytes & 7 & $0-10$ \\
\hline Eosinophils & 1 & $0-5$ \\
\hline Platelets (lakhs per $\mathrm{mm}^{3}$ ) & 75,000 & $1.5-4.5$ \\
\hline Blood urea (mg/dl) & 73 & $19-43$ \\
\hline Serum creatinine $(\mathrm{mg} / \mathrm{dl})$ & 1.1 & $0.8-1.5$ \\
\hline Total bilirubin (mg/dl) & 3.83 & $0.20-1.30$ \\
\hline Direct bilirubin (mg/dl) & 2.4 & $0.00-0.40$ \\
\hline
\end{tabular}

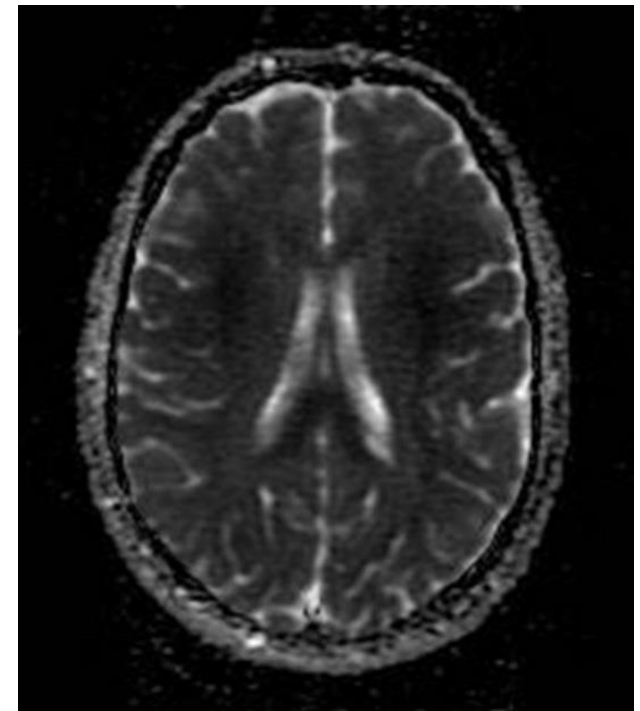

Figure 1: T2-weighted image of the brain showing hyper-intensity over the splenium, the corona radiata and the basal ganglia, with mild diffuse brain edema.

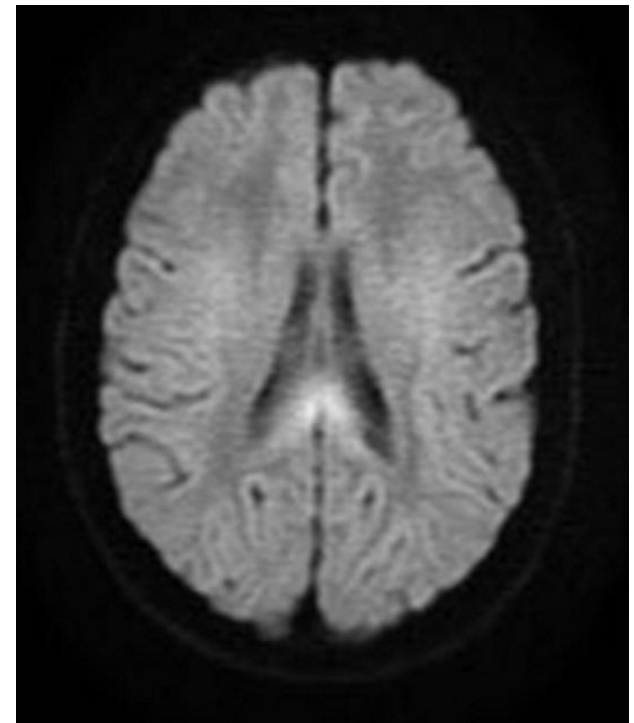

Figure 2: FLAIR MRI sequence showing hyper-intensity over the splenium, the corona radiata and the basal ganglia, with mild diffuse brain edema.

\section{Discussion}

Cerebral malaria is a potentially life threatening neurological complication of $\mathrm{P}$. Falciparum infection. It is characterized by rapid onset of loss of consciousness leading to unarousable coma, associated with convulsions including status, especially in children [3]. Though localizing signs are rare, it may presents with generalized hypertonia, opisthotonous, posturing and bruxism. Internuclear ophthalmoplegia is often found in such cases. It can also presents with 'symmetric encephalopathy' characterized by the presence of symmetrical upper motor neurone signs, like in our case $[3,6]$. The cause of death is not apparent most of the time. Progressive deterioration of brainstem function may lead to cardiac and respiratory arrest.

The pathology of cerebral malaria is found to be the sequestration of parasitized erythrocytes in the cerebral microvasculature, causing rupture of endarterioles proximal to the occlusive plugs, resulting in petechial ring hemorrhages in the white matter. The role of cytokine 'tissue necrosis factor' mediated up regulation of nitric oxide synthetase activity has also been shown in the pathogenesis of coma in cerebral malaria [7].

To summarize, if a patient from an endemic area of malaria, even if living in non-endemic area, presents with fever and neurological complications it is crucial to have the patient 
worked up for malaria. Considering globalization and large scale migration across countries, our case can have relevance in similar clinical situations involving migrant population in nonendemic countries for malaria.

\section{References}

1. Kochar SK, Kamath SD, Toshan N, Singhal Y, Kochar A. A case of Plasmodium vivax malaria presenting as acute cerebral infarct. J Vector Borne Dis 2017;54:197-200.

2. WHO Malaria Unit : Global malaria control. Bull World Health Organ 1993;71:281-287.

3. Newton CRJC, Hien TT, White N. Cerebral malaria. J Neurol Neurosurg Psychiatry 2000;69:433-431.

4. WHO. World Malaria Report 2014. WHO, Geneva. 2014. Available at http://apps.who.int/iris/bitstream/10665/144852/2/9789241564830_en g.pdf

5. A Profile of National Institute of Malaria Research. Estimation of True Malaria Burden in India. pp 91-99. Available at http://www.mrcindia.org/ MRC_profile/profile2/Estimation of true malaria burden in India.pdf

6. Garg R K, Karak B, Misra S. Neurological manifestations of malaria: An update. Neurol India 1999;47:85-91.

7. Idro $\mathrm{R}$, Marsh $\mathrm{K}$, John $\mathrm{CC}$, Newton $\mathrm{CR}$. Cerebral Malaria; Mechanisms of Brain Injury and Strategies for Improved NeuroCognitive Outcome. Pediatr Res 2010;68:267-274. 